\title{
A DONA DA TERRA JUPIRA DO TOMBENCI, SUAS CABOCLAS, SEUS CABOCLOS ${ }^{1}$
}

Marinho Rodrigues

Tata Luandenkossi

Tata Kambondo do Terreiro Matamba Tombenci Neto ${ }^{2}$

Marcio Goldman

Tata Sumbunanguê

Tata Mabaia do Terreiro Matamba Tombenci Neto ${ }^{3}$

Resumo: Este texto é a introdução de um pequeno livro, a ser publicado em breve, elaborado a partir das imagens obtidas na grande festa para os caboclos do Terreiro Matamba Tombenci Neto, em Ilhéus, na Bahia, realizada em setembro de 2019, quando também foi reinaugurada a cabana de sua cabocla principal, a Cabocla Jupira. Combinadas com fotografias mais antigas (algumas da década de 1940!), as imagens obtidas nessa festa homenageiam as caboclas, caboclos e encantados em geral e, mais particularmente, todas e todos que escolheram o Terreiro e suas filhas e filhos como sua morada. Algumas dessas fotografias foram reproduzidas ao final do texto.

${ }^{1}$ Como citar: RODRIGUES, Marinho; GOLDMAN, Marcio. A dona da terra: Jupira do Tombenci, suas caboclas, seus caboclos. Debates do NER, Porto Alegre, v. 2, n. 38, p. 315 - 336, 2020.

2 Presidente da Organização Gongombira de Cultura e Cidadania Ilhéus, Brasil. E-mail: gongombira@yahoo.com.br.

${ }^{3}$ Doutor em Antropologia Social; Professor Titular de Antropologia Social no Programa de Pós-Graduação em Antropologia Social, Museu Nacional, Universidade Federal do Rio de Janeiro; Pesquisador do CNPq e da FAPERJ, Brasil. E-mail: marcio.goldman@ gmail.com.

Debates do NER, Porto Alegre, ano 20, N. 38, P. 3 I 5-336, Ago./Dez. 2020 
Palavras-chave: Religiōes de Matriz Africana; Candomblé Angola; Bahia; Terreiro Matamba Tombenci Neto.

THE MISTRESS OF THE LAND. JUPIRA FROM THE TOMBENCI, HER CABOCLAS AND CABOCLOS

\begin{abstract}
This text is the introduction of a small book, to be published soon, prepared from the images obtained in the great party for the caboclos in the Terreiro Matamba Tombenci Neto, in Ilhéus, Bahia, Brazil, held in September 2019, when the hut of its main cabocla, Cabocla Jupira, was also reopened. Together with older photographs (some of them from the 1940s!), the images obtained in this party pay tribute to caboclas, caboclos and enchanted beings in general - more particularly to those who chose the Terreiro and its daughters and sons as their home. Some of these photographs were reproduced at the end of the text.
\end{abstract}

Keywords: African-American Religions; Angola Candomble; Bahia; Terreiro Matamba Tombenci Neto.

O Terreiro de Matamba Tombenci Neto foi fundado em 1885 por Tiodolina Félix Rodrigues, Yiatidu, em um local próximo a Ilhéus chamado Catongo, com o nome de Aldeia de Angorô, de quem Yiatidu era filha. Mais tarde, seu filho de sangue, Euzébio Félix Rodrigues (Tata Gombé, de Roxo Mucumbo - ver foto 01), levou o terreiro para a cidade Ilhéus, com o auxílio de Hipólito Reis (Dilazenze Malungo, de Zaze), africano que conhecera em Salvador. Lá, o terreiro passou a ser chamado Terreiro de Roxo Mucumbo, inquice de Tata Gombé. Na década de 1940, outra filha de Yiatidu — Izabel Rodrigues Pereira (Bandanelunga, filha de Zumbarandanda e conhecida como Mãe Roxa ou Dona Roxa) - assumiu o comando do terreiro, que passou a se chamar Nossa Senhora Sant'Ana Fé e Razão. Ainda na década de 1940, Marcelina Plácida (Quizunguirá, filha de Zaze, conhecida como Dona Massu, e filha-de-santo de Maria Jenoveva do Bonfim, Tuenda de Zambiapongo, do Terreiro Tombenci, em Salvador, filha de Cavungo e primeira 
mãe-de-santo da nação Angola) plantou definitivamente o terreiro, que passou a ser chamado Terreiro Senhora Sant'Ana Tombenci Neto. Em 1973, com o falecimento de Mameto Bandanelunga, sua filha de sangue, Hilsa Rodrigues Pereira dos Santos, tornou-se a mãe-de-santo da casa e no cargo permanece até hoje. Com Dona Ilza, como é conhecida, filha de Matamba e dijina Mukalê, o terreiro recebeu seu nome atual: Matamba Tombenci Neto (ver Mukalê 2011; Silva 2016; Goldman 2006).

Como se sabe, o candomblé é uma das religióes de matriz africana no Brasil. Uma das religióes cujo núcleo foi trazido pelos africanos para as Américas desde o século XVI. Como também se sabe, ao longo do tempo, essas religióes foram se articulando entre si e, também, incorporando, em maior ou menor grau, elementos de outras tradiçóes religiosas, indígenas, do catolicismo popular e do espiritismo. Esses elementos foram se transformando na medida em que iam sendo combinados e foram sendo combinados na medida em que se transformavam, gerando variantes religiosas muito parecidas quando olhadas de uma certa distância e bem diferentes quando olhadas de outra. O candomblé de nação Angola é uma dessas variantes e se caracteriza, principalmente, pelo culto que presta aos Inquices (as divindades de origem africana, que outras naçóes denominam orixás) e aos Caboclos.

Porque espalhado por praticamente todo o Brasil, do oeste da Amazônia ao litoral do Nordeste e do extremo norte do país ao Rio de Janeiro e São Paulo, podemos encontrar um conjunto de seres espirituais com características muito semelhantes, ainda que não idênticas. Cultuados em diferentes formas religiosas, esses seres são conhecidos como encantados e de forma mais comum como caboclos. São seres que não se confundem inteiramente nem com as divindades propriamente ditas, nem com os espíritos dos antepassados e dos finados em geral. Quase sempre, costumam ser pensados como vivos, seja porque são seres que passaram deste plano da existência para outro sem conhecer a experiência da morte (ou passando por uma experiência da

Debates do NER, Porto Alegre, ano 20, N. 38, P. 3 I 5-336, Ago./Dez. 2020 
morte muito especial), seja no sentido de que sempre existiram, habitaram e protegeram determinados territórios. Eles são os Donos da Terra.

Os mais velhos do terreiro contam que seus mais velhos contavam que os mais velhos deles contavam que quando chegaram aqui nessas terras, trazidos à força para trabalhar, tudo era muito difícil. Separados de suas famílias e de seus mais velhos, eles não sabiam falar a língua, não conheciam o lugar e eram tratados com muita crueldade por aqueles que os haviam roubado de casa.

Como diz o saudoso Seu Esmeraldo Emetério de Santana, grande Tata (Xicarangomo) do Terreiro Tumba Junsara, de Salvador, as pessoas das várias naçóes africanas que foram presas nas senzalas tinham que se ajudar umas às outras, tinham que trocar entre elas aquilo que cada uma conhecia:

"Foi assim que eles fizeram. Misturaram, porque eles, na senzala, tinha ali de todas as 'naçóes' e, quando era possível, eles faziam qualquer coisa das obrigaçooes deles, então cada um pegava um pedaço, faziam uma colcha-de-retalhos, um cozinhava isso, outro cortava aquilo, outro pegava, porque eles tinham tempo limitado para tal e faziam. A mesma coisa fez-se no cântico. Um, 'eu sei tal cantiga', outro, 'eu sei tal', e todos cantavam, e entáo o 'santo' aceitava, e não ficou somente uma 'nação' para fazer aquele tipo de obrigação" (Santana 1984, p. 36).

Foram então os conhecimentos, os saberes das pessoas diferentes reunidas, suas religióes, suas crenças, suas práticas, foi tudo isso que permitiu que elas resistissem e sobrevivessem numa situação tão difícil. Para isso elas tiveram que ter muita solidariedade, tiveram que trocar muitas coisas entre si, cada uma ensinando às outras o que sabia e aprendendo com elas o que não sabia.

Mas ninguém conhecia a nova terra, seus segredos, suas dificuldades, as línguas e os costumes dos que já estavam aqui quando eles chegaram. Por isso era muito difícil fugir e mais difícil ainda sobreviver depois da fuga. Foi 
assim que aqueles que tinham sido trazidos à força da África encontraram aqueles que já viviam nas Américas e que também estavam sendo ameaçados pelos brancos europeus que queriam explorar e matar uns e outros. Assim, o encontro entre africanos e indígenas foi diferente daquele com os europeus. Enquanto estes queriam obrigá-los a aceitar sua língua, seus costumes, sua religião, entre africanos e indígenas, como mostrou o grande Abdias do Nascimento, o que houve foi um livre intercâmbio, uma aceitação voluntária daquilo que cada cultura podia oferecer à outra:

"Só merece o nome de sincretismo o fenômeno que envolveu as culturas africanas entre si, e entre elas e a religião dos índios brasileiros" (Nascimento 1978, p. 108-109).

Foi desse modo que nos quilombos, nas aldeias, nos terreiros, essa aliança foi sendo construída. E ela foi construída também na religião. Assim Luiz Sérgio Barbosa, antigo pai-de-santo membro da Federação de Cultos Afro-Brasileiros da Bahia, explica a entrada dos caboclos nas religióes de matriz africana, que teria ocorrido como resultado das "andanças" dos caboclos nos terreiros de candomblé:

"Os festejos (...) eram presenciados pelos Caboclos (Índios). Os mesmos manifestavam a vontade de participar, em razão dos encontros casuais entre escravos e índios. (...) Os Caboclos espiavam mas não era permitida sua participaçáo. Os africanos vetavam. Os caboclos passaram a reclamar. Alegaram que os africanos vindos para o Brasil nada trouxeram e quando aqui chegaram se valeram do que encontraram, e tudo que existia aqui no Brasil era dele, o caboclo. As terras, as folhas, os rios, as pedras e tudo mais que os africanos estavam usando era de propriedade dos caboclos (Índios). Com esse entendimento os caboclos começaram a romper a barreira com o aparecimento de incorporaçōes de caboclos nas pessoas possuidoras de mediunidade" (Barbosa 1984, p. 88-89).

Como lembra ainda Barbosa, alguns dizem que os caboclos são espíritos de índios. É o caso de Mãe Lindinalva, do Terreiro Casa das Minas de

Debates do NER, Porto Alegre, ANo 20, N. 38, P. 3 I 5-336, Ago./Dez. 2020 
Thoya Jarina do Maranháo, que era dirigido pelo falecido Pai Francelino de Shapanan. Máe Lindinalva dizia que seu próprio Caboclo (Pedra Preta) "é índio, mas se porta como caboclo para o povo entender (...). Não se considera egum (espírito de morto), mas sua 'pajelança’ é como de egungum, dos índios mortos que já foram grandes caciques, tuxauas, morubixabas" (Pai Francelino de Shapanan 2004, p. 323). Como explica o próprio Pai Francelino, o caboclo se transforma: "o caboclo, em suas diferentes formas, se misturou", ele "é o índio civilizado que veio para a cidade, que se misturou com o branco e até mesmo com o africano" (Pai Francelino de Shapanan 2004, p. 322). Há também quem sustente que os caboclos são divindades dos índios que se incorporaram ao panteão afro-brasileiro; e mesmo quem diga que os caboclos são espíritos de pajés indígenas ainda vivos que têm o poder de enviar suas almas para outros lugares. $\mathrm{O}$ importante, conclui Barbosa (1984, p. 67), é não querer saber demais: "eu só sei que existem os caboclos".

Ainda mais porque os caboclos têm a capacidade de aparecer de muitas maneiras diferentes. Como escreve ainda Barbosa (1984, p. 89-94)

"Há caboclo que incorpora nas pessoas, dizendo-se ser verdadeiro, quando não é verdade. Os mesmos não são nativos das aldeias. São orixás africanos que, na incorporação, dizem ser caboclo nativo. O caboclo, ele desencarnado é um espírito. Mas você há de analisar que há caboclo serviçal e caboclo chefe. E nós não podemos, aqui, analisar, há quantos milênios existem os caboclos e a sua desencarnação. Então ele pode ser um caboclo espírito porque nós não vamos qualificar o caboclo como egum e ele pode ser um caboclo deificado. Porque ele vem cá, incorpora, com o prodígio dele, faz o bem. Quantas pessoas são beneficiadas pelo caboclo? E o que ele diz é verdade. E vai trabalhar em benefício disso. Portanto ele está chegando ao ponto de ser deificado (...). $\mathrm{Na}$ linha de caboclo nós não qualificamos como egum. Porque o egum tem muita conotação. A trajetória do egum é diferente dos ensinamentos, dos conhecimentos e da existência do caboclo. Eles são espíritos e podem ser muito evoluídos e, como eu acabo de dizer, o deificado é o orixá, o deificado 
pode ser o caboclo, que vem na terra implantando o seu prodígio, cuidando das pessoas" (Barbosa, 1984, p. 89-94).

Seu Nezinho, umbandista de Juazeiro do Norte, assim explica ao pesquisador Luiz Assunção o que é um caboclo:

"Caboclo é índio. É índio, sim. Agora eu acho que varia. Um dia, um caboclo que ele venha, ele desce em várias linhas, varia. Tem caboclo que desce como Exu. Varia, isso aí muda de linha. Uma entidade só tem capacidade de puxar sete cantos. É aí que ele muda de linha. Então, tem caboclo que não desce como Exu. E já tem outros que descem como Exu. Vamos supor, Caboclo Arranca Toco, na linha esquerda ele vem como Exu. Se a pessoa está acostumada a trabalhar linha cruzada, aí desce tudo no mundo. Aí mistura tudo" (Assunção 2001, p. 186).

Naiana - mãe pequena do Terreiro do Caboclo Juremeira, de Dona Otília, em Belmonte, explicou para a pesquisadora Bianca Soares (2014, p. 37-38) que os caboclos se distinguem dos eguns propriamente ditos porque "se diferenciaram" desses espíritos ao escolher trabalhar para as divindades, tornando-se, assim, seus "mensageiros": "os orixás viveram e adquiriram poderes que quando morreram conseguiram se diferenciar e voltar. Os pretos velhos e caboclos também".

Do mesmo modo que acontece em todo o Brasil, também no Terreiro de Matamba Tombenci Neto, em Ilhéus, os caboclos são fundamentais. Como conta Mãe Hilsa Mukalê, mãe-de-santo do terreiro há mais de 45 anos, e iniciada no candomblé há mais de 70 anos, o próprio terreiro teve início com os caboclos:

"O início de tudo foi com a minha avó, mãe da minha mãe, Tiodolina Félix Rodrigues, Yiatidu. Ela tinha um pouco da mistura de negro com índio. Quando minha avó chegou aqui vindo de Castro Alves ela veio a ter essa casa em um lugar perto de Ilhéus chamado Catongo. Isso foi em 1885, e como ela era de Angorô, chamava o lugar de Aldeia de Angorô. Lá ela tinha uma casa de taipa com uma camarinha onde ela cuidava do santo; lá ela falava sobre

Debates do NER, Porto Alegre, ano 20, N. 38, P. 3 I 5-336, Ago./Dez. 2020 
o candomblé para as pessoas, saía com elas para o mato para catar as folhas, as ervas, fazer as garrafadas, os banhos, as oferendas. Ela ficou lá por muito tempo cuidando de tudo isso e era uma coisa muito natural, praticamente no meio da mata, convivendo muito com a parte dos caboclos."

Mãe Hilsa conta, também, que foi o filho mais velho de Yiatidu, Euzébio Félix Rodrigues (Tata Gombé), quem trouxe o terreiro para Ilhéus, já no bairro da Conquista, na Ladeira do Jacaré: "meu tio tinha um caboclo que se chamava Ouro Preto. Esse caboclo era muito rigoroso, não era de falar muito, ele era de 'sim, sim', 'não, não'”. É por isso que até hoje a gente canta:

Quando eu venho de Rio de Conta,

Passeando pelas belas ruas.

Quando eu venho de Rio de Conta,

Passeando pelas belas ruas.

Olhe que beleza,

Seu Ouro Preto no sair da lua.

Olhe que beleza,

Seu Ouro Preto no sair da lua.

E uma das pessoas que fizeram suas primeiras obrigaçóes com Euzébio foi Dona Júlia Cajiberu, que faleceu há pouco tempo: "ela também tinha um caboclo muito bonito, chamado Caipó, um caboclo que dançava de um jeito só dele, muitas vezes em cima de uma perna só”.

Depois de Euzébio quem assumiu o terreiro foi sua irmã mais nova, Izabel Rodrigues Pereira, filha de Zumbarandanda (Nãnã), conhecida por todos como Mãe Roxa e que tinha como dijina Bandanelunga. Ela é mãe de sangue de Mãe Hilsa Mukalê e conduziu o Terreiro de Matamba Tombenci Neto por cerca de 30 anos. Dona Roxa recebia três caboclos: Seu André Caitumba (ver foto 02), um boiadeiro; mais raramente, o caboclo Seu Trovezeiro; e, mais raramente ainda, ela ainda recebia o caboclo Ouro Preto, de Euzébio. Mãe Hilsa Mukalê conta que: 
"Desde mocinha, minha mãe começou a receber esse caboclo, Seu André Caitumba, um boiadeiro que continua aqui comigo até hoje. Até hoje ele responde no jogo. Eu nunca quis me separar dele. Ele era e ainda é o puxa-folha da casa. Eu mesma tenho uma cabocla, Jupira, que é a segunda puxa-folha da casa (ver foto 03). Primeiro, vou a Seu André e o que ele ordena passa para a Cabocla. Até hoje eu ponho Seu André na frente da minha própria cabocla. Porque nas casas de candomblé, principalmente da nação angola, e também nas casas de umbanda, há caboclos que são recebidos como boiadeiros, que era o caso desse caboclo de minha mãe, André Caitumba. Na verdade, o nome dele era Inguê Caitumba, e quando a matéria dele ainda estava na vida material, ele trabalhava nos campos, boiando, pegando suas boiadas. Ele era um líder da sua aldeia e isso significava que ele ia voltar. Ele voltou e quando ele trabalhava com a minha mãe na parte de boiadeiro dava o nome de Inguê Caitumba (mas todo mundo conhecia como André Caitumba); mas ele também trabalhava em sessóes espíritas de mesa branca (com uma senhora que já desencarnou também), onde ele respondia como André. A gente cantava assim para ele:

Quem vem lá?

Ô sou eu, Caitumba

Quem vem lá?

Caitumba sou eu

Quem vem lá?

Ô sou eu, Caitumba

Quem vem lá?

Caitumba sou eu

Caitumba é meu, no Catimbeuá,

Caitumba é meu, no Catimbeuá.

Ô Caitumba, aldeia nova no Jiquiriçá,

Ô Caitumba, aldeia nova no Jiquiriçá.

Ô Caitumba é meu, no Catimbeuá,

Caitumba é meu, no Catimbeuá.

Ô Caitumba, aldeia nova no Jiquiriçá, 
Ô Caitumba, aldeia nova no Jiquiriçá.

Porque os caboclos vêm do tempo dos encantos, da época em que se trabalhava com os encantados. Tanto da parte indígena, das florestas (de onde vêm caboclos como Tupinambá, Tupiaçu, Tupiniquim, Pena Verde e tantos outros; e caboclas como Jupira, Indaiá, Jurema, Iracema e tantas outras). Os caboclos e as caboclas vêm das pessoas que desencarnaram e os caboclos voltaram para dar continuidades aos trabalhos que elas faziam na época em que estavam do lado material. Para os encantados, a gente cantava assim:

Oli oli olá.

Dom João do Rio Verde.

Dom João do Rio Verde.

Dom Joáo do Rio Verde.

Aí eram três irmãos que saíram a passear,

Eram três irmãos que saíram a passear.

João das Pedras, João da Lage, João de Catingombá."

O que Mãe Hilsa Mukalê nos explica é que os caboclos são os espíritos das pessoas que viveram na terra, índios, boiadeiros, mas também outros como os marinheiros/marujos, por exemplo:

"Os marinheiros são um pouco diferentes porque vêm do lado da marujada, eram comandantes de navios, marujos, cada um com sua posição... Quando essa pessoa muda de plano, ou seja, sai do material para o lado espiritual, seus espíritos vão ter, como eu disse, a purificação, e voltar na linha da marujada. Aí a gente canta assim:

Seu Marinheiro é hora,

É hora de viajar.

Seu Marinheiro é hora,

É hora de viajar.

É céu, é mar,

Seu Marinheiro olha o balanço do mar." 
Ou seja, dependendo do que pessoas fizeram em suas vidas quando habitavam o plano material da terra, elas podem retornar:

"Eles voltam! Eles morrem, vão embora, as pessoas às vezes pensam que morreu acabou, mas não é bem assim não! Eles passam para o outro lado, mudam de plano, vão para o plano espiritual. E lá, podem passar por um processo de purificação que só Zâmbi pode entender. A terra se encarrega de destruir a carne, mas o espírito vai andar e vai ser purificado dependendo do merecimento na terra em que se viveu materialmente. Zâmbi pode purificá-los e agraciá-los para que caminhem nos caminhos de luz, e aí eles voltam, procurando justamente aquela família que tinham deixado. No meio daquela família, alguém que trouxe um dom de nascimento começa a ter visôes e quando chega em uma casa de candomblé ou de umbanda alguém vai jogar os búzios e dizer o que aquele espírito está explicando e por que está voltando. E é aí que a pessoa escolhida vai dar continuidade, sob a orientação da mãe-de-santo ou do pai-de santo. Alguns escolhidos não precisam abrir casa, mas têm uma missão: recebem intuição e vão trabalhar ajudando os outros, fazendo orações, conhecendo, limpando, dando banhos e muitas outras coisas. É uma missão!"

No Tombenci, depois do Caboclo Ouro Preto e de Seu André Caitumba, a cabocla principal do terreiro passou a ser a Cabocla Jupira, que é recebida por Mãe Hilsa Mukalê e que traz sabedoria e muita alegria para todas e todos sempre que vêm ao terreiro. Máe Hilsa conta como ela começou a receber essa linda cabocla:

"Quem primeiro veio me dizer quem era a cabocla que Mameto Matamba mandou para eu receber foi a finada Maristela, uma pessoa de muita vidência. Uma vez ela me procurou e disse:

- 'Comadre Hilsa, eu tive um sonho e quero contar para a senhora. No sonho, eu via a senhora virada numa cabocla, uma menina. Não era cabocla velha, mas uma menina, uma mocinha. Ela disse que o nome dela era Nhá Jupira. Mas não sei, não é? Porque esse negócio de sonho é assim, às vezes não é nada’. 
Isso aconteceu perto do toque para a cabocla descer. Maristela veio para ver se o sonho era certo mesmo. Aí, minha mãe-de-santo cantou para os caboclos dela e uma cantiga para Seu André; aí cantou três zuelas e a Cabocla veio. Todo mundo achou estranha a chegada dela, de barravento. Quando chegou, deu o ilá dela, parou, olhou e cantou:

Eu tava lá na Junceira,

Lá eu estava.

Aí seu André mandou me chamar.

Lá eu estava.

Quem quiser saber o meu nome,

Lá eu estava.

É Jupira do Tombençá,

Lá eu estava

Quer dizer, seu André mandou chamar a Cabocla Jupira na sua aldeia e ela atendeu a chamada para, junto com ele, responder no meu jogo. Eu tenho Seu André como uma pessoa mais velha e os dois comandam, são os puxa-folha da casa. Todo mundo se entusiasmou quando viu a Cabocla dançando, todo mundo queria tocar para ela. Porque ela não dançava descarreirada, era cadenciado, do jeito dela. Todo mundo virou fâ da Cabocla, que tinha esse repertório que não é de mais ninguém. Eu mesma não sei de onde ela tira esse repertório de cantigas tão bonitas. Eu faço algumas composições e Jupira tem várias zuelas feitas por mim. As pessoas me perguntam como faço essas composições, mas eu não sei! Vem na minha cabeça e vou botando ali, procurando a letra e fazendo. Tem várias. Estas, por exemplo:

Eu sou cabocla, eu venho de longe, do lado de lá.

A minha macamba fica embaixo do Juremá.

Pego na raiz, sento na dissiça pra trabalhar.

E vou dar conselho praquele filho que precisar.

Eu sou cabocla, eu sou guerreira.

$\mathrm{Na}$ minha aldeia, sou raizeira. 
Eu sou cabocla, eu sou cabocla e sou guerreira.

$\mathrm{Na}$ minha aldeia sou cabocla curandeira.

Ô inauê, ô inauê, ô indaiá.

Eu sou cabocla do reinado de angolá.

Ô inauê, ô indaiá.

Minha macamba debaixo do juremá.

A noite já vem caindo,

nas matas escureceu.

Cadê a Cabocla d'Aruanda

que até agora não apareceu?

Cadê a Cabocla d'Aruanda

que até agora não apareceu?

Ai moré moré moré

Ai moré moré moré

Ai moré moré moré

Moré

Aqui no terreiro houve muitos caboclos que marcaram época: Tupinambá, de Maria Calenoá; Caipó, de Dona Julia Cajiberu; Jequiriçá, da finada Augusta; Sete Serras, de Matilde; Tupiniquim, da minha tia, que era muito bravo e quando chegava não demorava muito, era como se estivesse na aldeia flechando; e muitos e muitos outros. Esses Caboclos, quando chegavam, fechavam mesmo! Faziam um candomblé de caboclo para ninguém botar defeito. Os Tata Cambondo gostavam demais e tocavam com gosto muito. Ave Maria! Quando dizia "vai virar para caboclo", todo mundo sabia que ia pegar fogo. Que ia virar o candomblé de Angola para Caboclo, com aquelas zuelas que fazem todo mundo virar. Não ficava para ninguém, todo mundo ia virando, um para lá, outro para cá. O candomblé fazia gosto mesmo!"

Ninguém deve imaginar, contudo, que essa história e essas histórias fazem apenas parte do passado. Ao contrário, como Mãe Hilsa Mukalê chama a atenção, essa é uma história viva, do presente e, ainda mais, do futuro: 
"Agora também tem muitas caboclas e caboclos muito bonitos. A começar pela da minha neta Gleide: quando demos a obrigação para a cabocla, ela respondeu e avisou que viria de vez na obrigação de cinco ou de sete anos. Ela deu o nome (Cabocla Indaiá) e contou que é irmã da minha Cabocla Jupira. A gente levou uma temporada sem tocar para caboclo porque a macamba da Cabocla Jupira era aberta, como ela queria porque caboclo não tem casa. Mas aí tem o problema da segurança, malandro tocando fogo nas casas, queimando cerca... Ficamos preocupados e tivemos que mudar o ritmo e modificar o lugar. Deu muito trabalho para os caboclos darem a licença para a gente mudar, foi preciso muito malembe, muito agô! Mas chegou uma hora em que eles cederam e nós pudermos retomar.

Porque a gente continua, a gente segue, a gente vive de ajudar as pessoas, é uma missão que eu tenho. São três gerações passadas! Vamos devagarinho, fazendo uma coisa hoje, outra amanhã. Recebemos um pouquinho de um, um pouco de outro, e é assim que conseguimos fazer nossas coisas, como a macamba da Cabocla Jupira (ver fotos 4 e 5). A partir disso a gente vem juntando a geração nova, que já está dando passagem aos Caboclos, cada um tem o seu. Fizemos essa festa em setembro de 2019 (ver fotos 06 a 09) que chamou muita atençáo porque foi muito bonita, e a gente vai repetir todo ano para que os caboclos tenham a oportunidade de vir para ver as pessoas e fazer essa festa bonita como foi a festa da minha Cabocla Jupira com Seu André, boiadeiro da minha mãe, e com Catendê, que é o inquisse da minha irmã, que é como se fosse um Oxóssi, um índio. Esses são os três que ficam lá dentro da macamba. E a gente vai continuar. Xeto Maromba Xeto!”.

\section{REFERÊNCIAS}

ASSUNÇÃO, Luiz. Os Mestres da Jurema. Culto da Jurema em Terreiros de Umbanda no Interior do Nordeste. In: PRANDI, Reginaldo (org.). Encantaria Brasileira: o Livro dos Mestres, Caboclos e Encantados. pp. 182-215. Rio de Janeiro: Pallas, 2001. 
BARBOSA, Luiz Sérgio. A Federação Baiana do Culto Afro-Brasileiro. In: Encontro de Naçóes de Candomblé. Salvador: Inamá/CEAO-UFBA, 1984.

GOLDMAN, Marcio. Como Funciona a Democracia. Uma Teoria Etnográfica da Política. Rio de Janeiro: Editora 7Letras, 2006.

MUKALÊ, Mãe Hilsa (Hilsa Rodrigues Pereira dos Santos). Do Lado do Tempo. O Terreiro de Matamba Tombenci Neto (Ilhéus, Bahia) - Histórias Contadas a Marcio Goldman. Rio de Janeiro: Editora 7Letras, 2011.

NASCIMENTO, Abdias do. O Genocídio do Negro Brasileiro. Rio de Janeiro: Paz e Terra, 1978.

SANTANA, Esmeraldo Emeterio de. Nação-Angola. In: Encontro de Naçóes de Candomblé: 35-47. Salvador: Inamá/CEAO-UFBA, 1984.

FRANCELINO DE SHAPANAN. Entre Caboclos e Encantados. Mudanças Recentes em Cultos de Caboclo na Perspectiva de um Chefe de Terreiro. In: PRANDI, Reginaldo (org.). Encantaria Brasileira: o Livro dos Mestres, Caboclos e Encantados. pp. 318-330. Rio de Janeiro: Pallas, 2004.

SILVA. Ana Claudia Cruz da. Devir Negro: Uma Etnografia de Encontros e Movimentos Afroculturais. Rio de Janeiro: Papéis Selvagens, 2016.

SOARES, Bianca Arruda. Os Candomblés de Belmonte: Variação e Convenção no Sul da Bahia. Rio de Janeiro: Museu Nacional (Tese de Doutorado), 2014. 


\section{FOTOGRAFIAS}

Fotografia 01 - Euzébio Félix Rodrigues (Tata Gombé), em torno de 1925 (acervo do Terreiro Matamba Tombenci Neto)

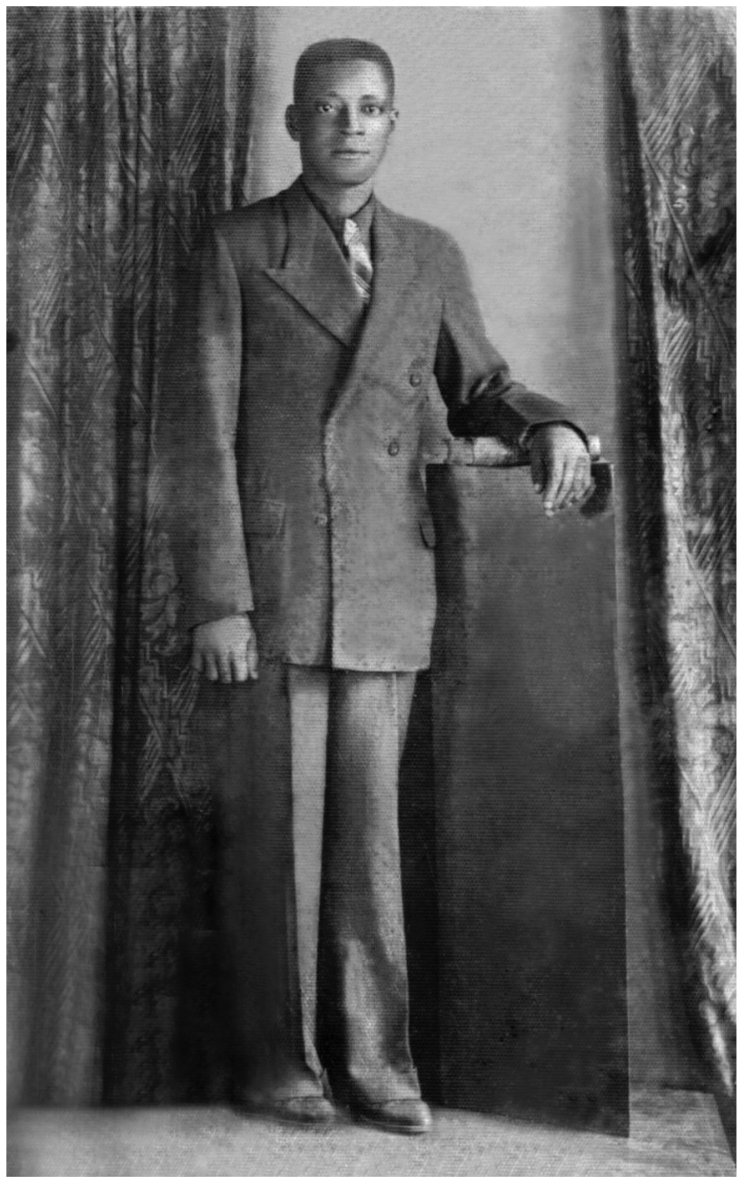

Debates do NER, Porto Alegre, ano 20, N. 38, P. 3 I 5-336, Ago./Dez. 2020 
Fotografia 02 - Seu André Caitumba, caboclo boiadeiro de Izabel Rodrigues Pereira, Dona Roxa (Bandanelunga), em torno de 1955 (acervo do Terreiro Matamba Tombenci Neto)

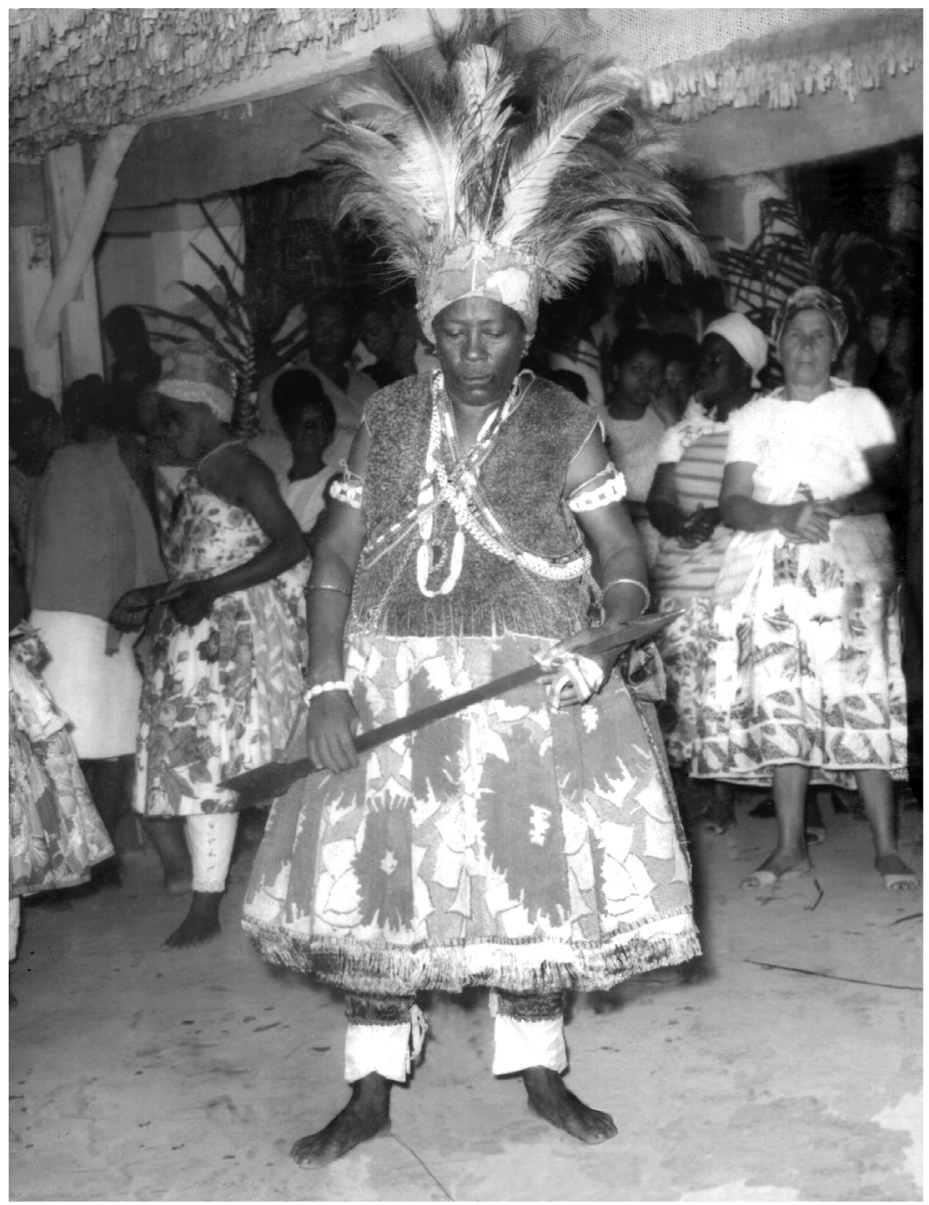

Debates do NER, Porto Alegre, ano 20, N. 38, P. 3 I 5-336, Ago./Dez. 2020 
Fotografia 03 - Cabocla Jupira, de Hilsa Rodrigues Pereira dos Santos, Dona Ilza (Mameto Mukalê), 1983 (acervo do Terreiro Matamba Tombenci Neto)

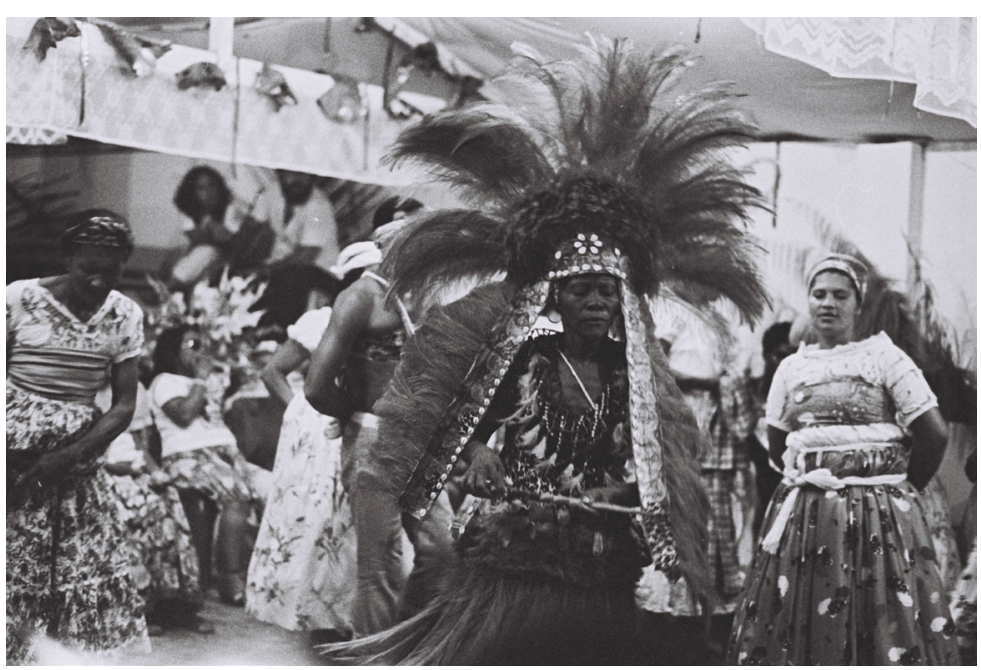


Fotografia 04 - Cabocla Jupira, de Hilsa Rodrigues Pereira dos Santos, Dona Ilza (Mameto Mukalê), 2019 (acervo do Terreiro Matamba Tombenci Neto)

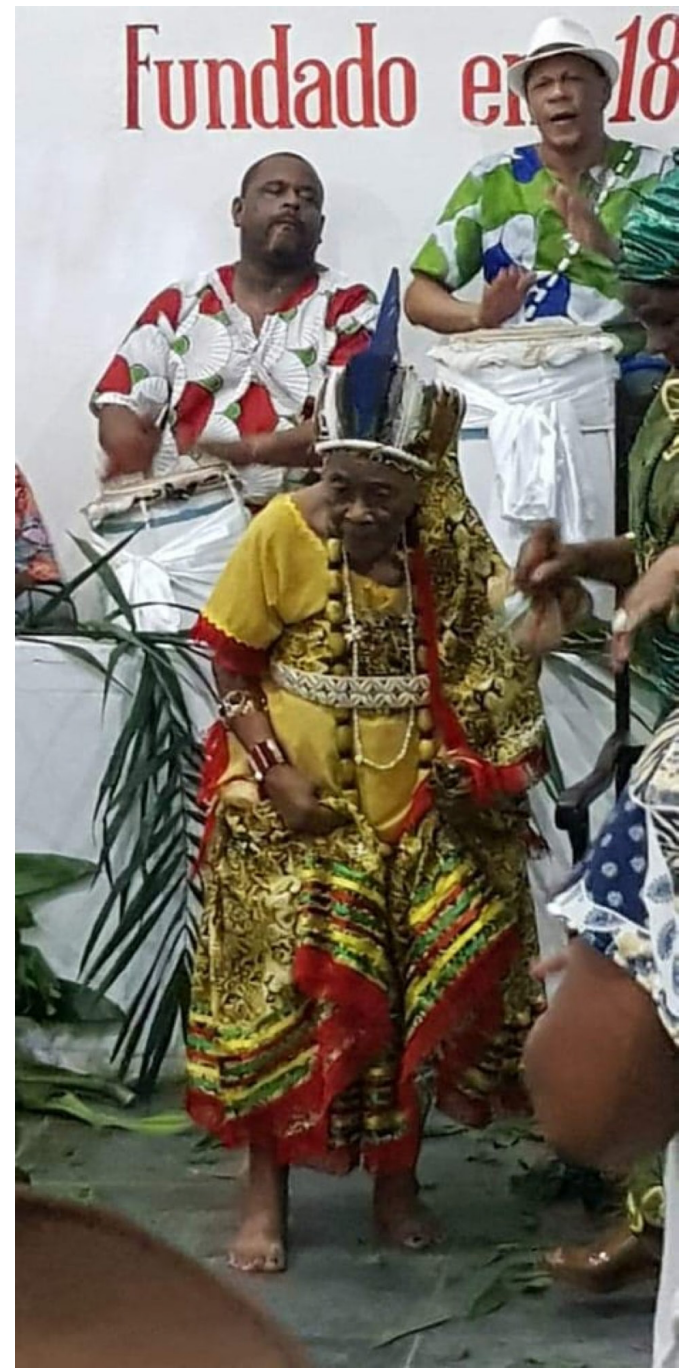

Debates do NER, Porto Alegre, ano 20, N. 38, P. 3 I 5-336, Ago./DEZ. 2020 
Fotografia 05 - Cabocla Jupira, de Hilsa Rodrigues Pereira dos Santos, Dona Ilza (Mameto Mukalê), 2019 (acervo do Terreiro Matamba Tombenci Neto)

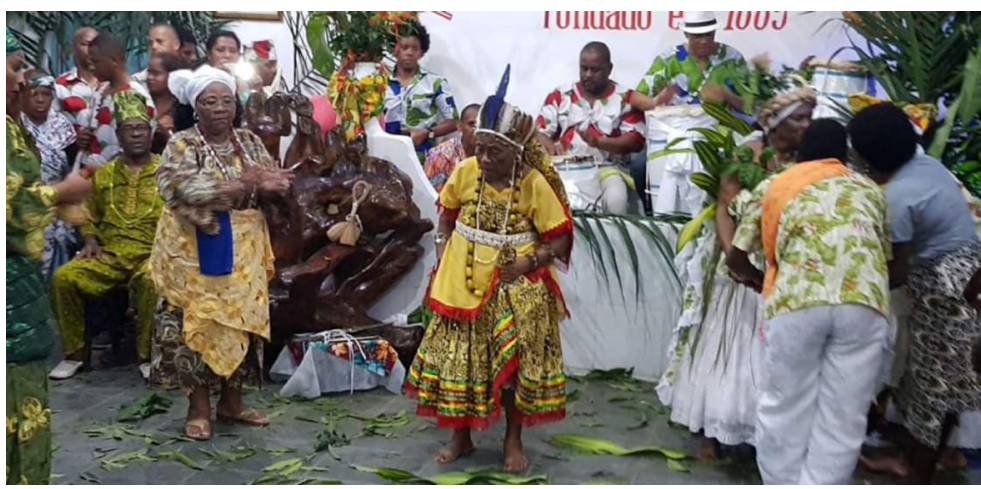

Fotografia 06 - Mameto Mukalê e um dos caboclos do Terreiro Matamba Tombenci Neto na festa de reinauguração da macamba (cabana) da Cabocla Jupira, em setembro de 2019 (acervo do Terreiro Matamba Tombenci Neto)

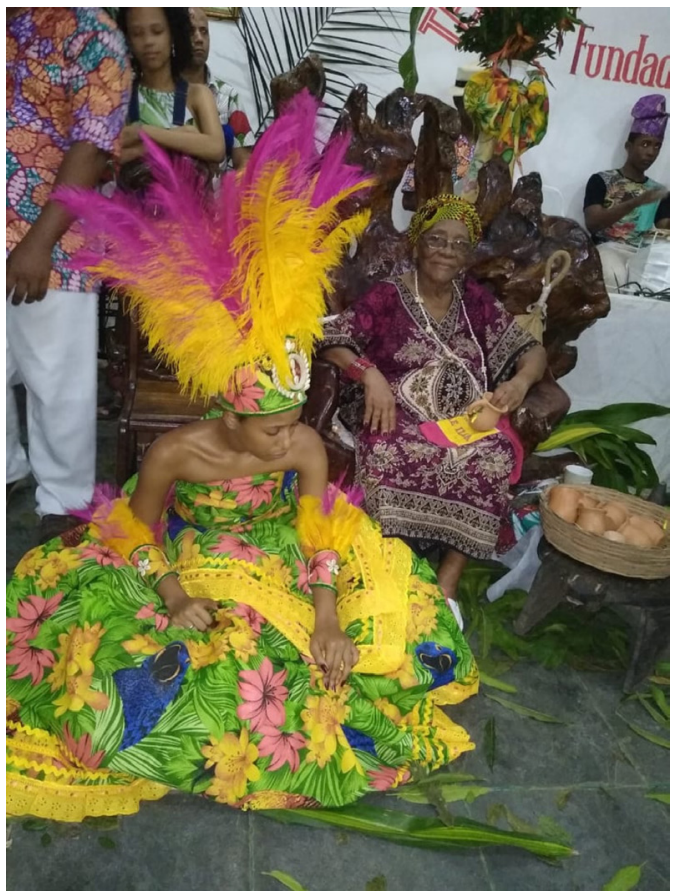


Fotografias 07, 08, 09 - Caboclas e caboclos do Terreiro Matamba Tombenci Neto na festa de reinauguração da macamba (cabana) da Cabocla Jupira, em setembro de 2019 (acervo do Terreiro Matamba Tombenci Neto)
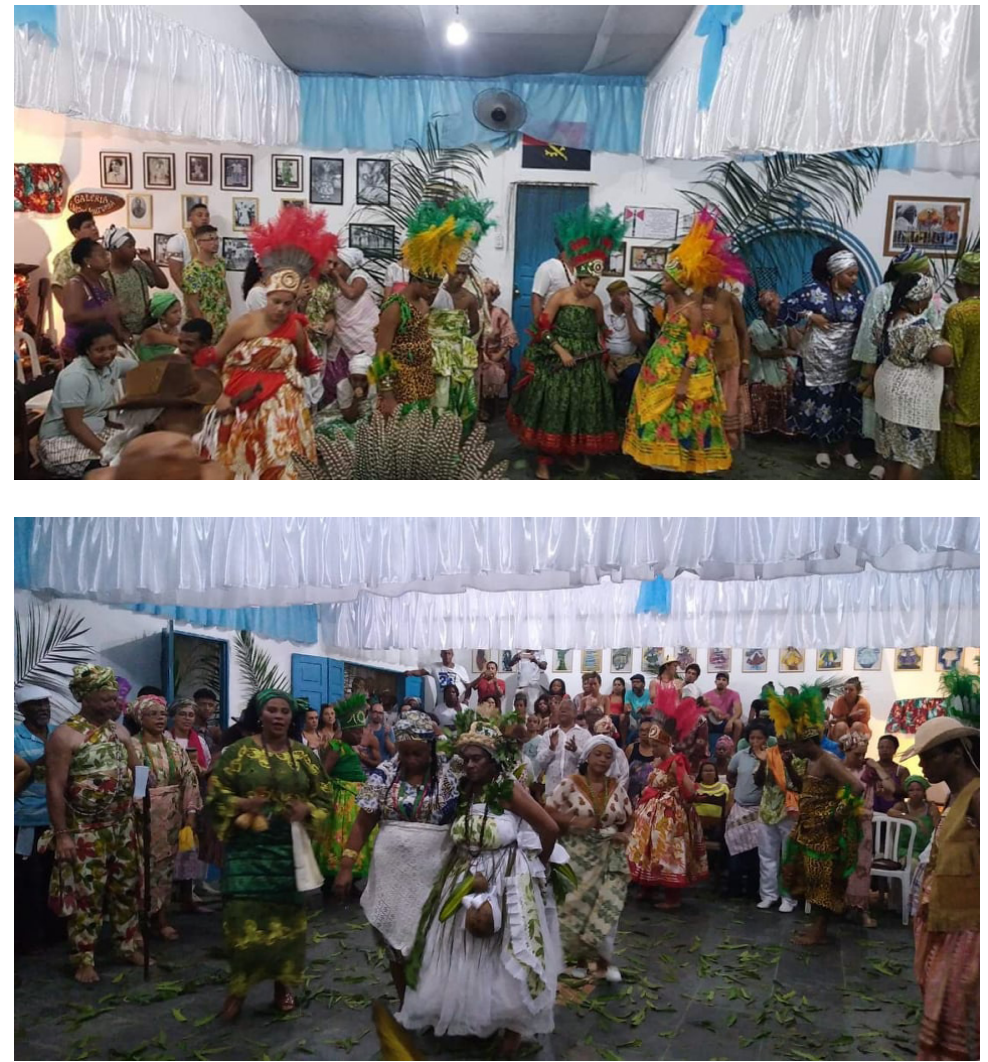

Debates do NER, Porto Alegre, ano 20, N. 38, P. 3 I 5-336, Ago./DEZ. 2020 


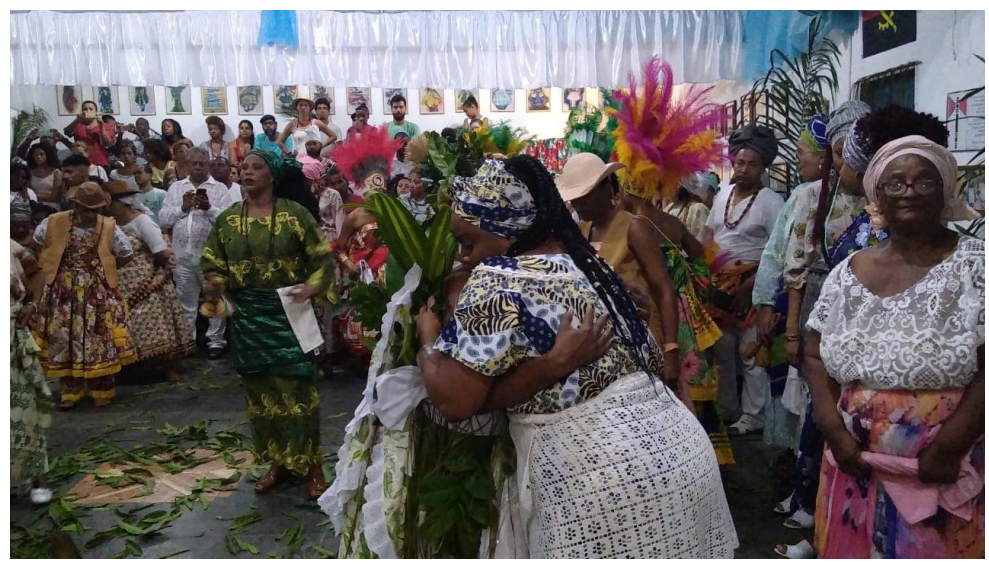

Recebido em: 07/08/2020

Aprovado em: 28/09/2020 

ARTIGOS 